\title{
Map of Quinta do Lorde Bay - Madeira Island
}

João G. Monteiro ${ }^{1}$ and Jesús Jiménez López ${ }^{2}$

${ }^{1}$ MARE-Madeira

${ }^{2}$ Affiliation not available

May 13, 2020 


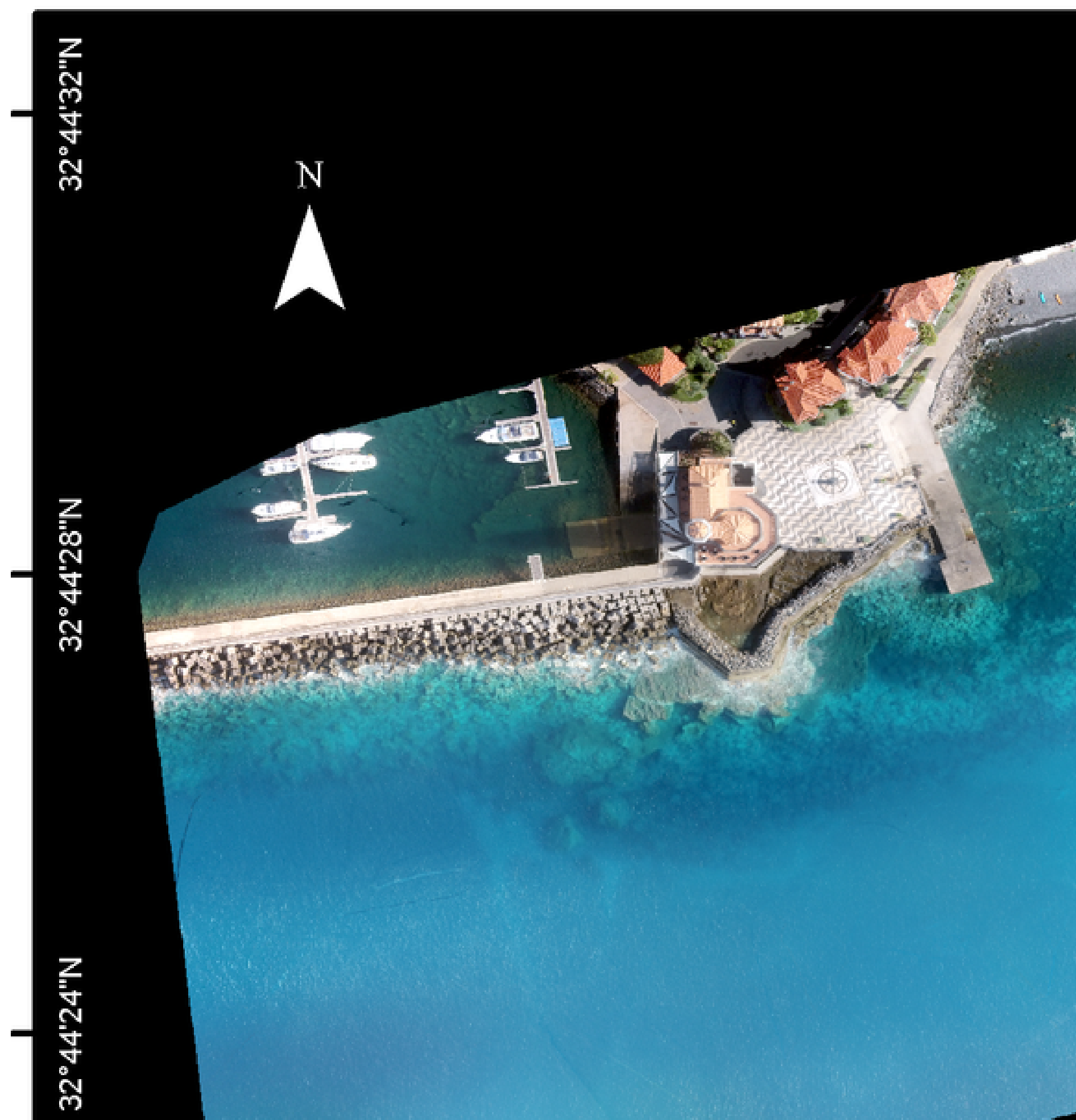


